\title{
PENGARUH TEMAN SEBAYA DAN PRESTASI BELAJAR EKONOMI TERHADAP PERILAKU KONSUMSI SISWA SMA KHADIJAH SURABAYA
}

\begin{abstract}
Lisa Hadija*
ABSTRACT

This study aimed to determine influences of peer and economics learning achievement on students' consumption behavior. This study is explanatory research using a quantitative approach. The population covers 192 students of grade X at Khadijah Senior High School of Surabaya. Samples are 130 students which determined by using simple random sampling technique, with Slovin formula. The data were collected using questionnaires and documentation. The data were analyzed quantitatively using simple and multiple linear regression. The hypothesis was tested using the t test technique and F test with the help of SPSS software. Based on the research results, it was concluded that: (1) There is a partial significant influence of peer on students' consumption behavior. (2) There is a partial influence of economics learning achievement on students' consumption behavior, and (3) There are simultaneous significant influences of peer and economics learning achievement on students' consumption behavior.
\end{abstract}

Keywords: Peer, Economics Learning Achievement, Student Consumption Behavior.

\section{PENDAHULUAN}

$\mathrm{P}^{\mathrm{s}}$ erilaku konsumen menurut pandangan masyarakat secara umum adalah suatu kajian tentang bagaimana seseorang membeli atau melakukan konsumsi atas suatu produk. Sedangkan menurut Kotler dan Amstrong (2012: 134), perilaku konsumen dapat diartikan sebagai perilaku pembelian konsumen akhir, baik individu maupun rumah tangga, yang membeli produk untuk konsumsi personal.

Fenomena yang terjadi di SMA Khadijah Surabaya atas pengaruh teman sebaya terhadap perilaku konsumsi siswa dapat diketahui dalam keseharian mereka. Diantara siswasiswi, memiliki banyak persamaan model dan merk atas barang-barang yang digunakan di tempat umum, seperti memiliki telepon genggam yang bermerk sama, mengenakan pakaian dan asesoris (jam tangan, sepatu, dll) yang sama, menonton film dan jenis musik yang sama, mengidolakan aktor dan aktris yang sama, dan mengkonsumsi makanan dan minuman yang sama pula. Hal ini mengindikasikan adanya pengaruh kelompok rujukan teman sebaya terhadap perilaku konsumsi siwa-siswi tersebut, yang perlu untuk dibuktikan dengan penelitian ini.

Perilaku konsumen remaja atau siswa cenderung dipengaruhi oleh teman sebayanya selain keluarga. Hal ini sejalan dengan pendapat Peter dan Olson (2010: 335) yang menyatakan bahwa selain ibu dan ayah, keputusan pembelian pada anak-anak dan orang

*) Guru SMA Khadijah Surabaya 
dewasa keduanya sangat dipengaruhi oleh teman sebayanya.

Schiffman dan Kanuk (2008: 308) menegaskan bahwa kebanyakan anak-anak pra remaja memperoleh norma-norma perilaku konsumen mereka melalui pengamatan terhadap orang tua dan saudara kandung mereka yang lebih tua, sebagai model dan sumber petunjuk dalam pembelajaran materi konsumsi atas barang-barang pokok. Sebaliknya para remaja yang berusia belasan tahun mungkin menjadikan teman-teman mereka sebagai model perilaku konsumsi yang dapat diterima. Jadi bagi remaja yang berusia belasan tahun, perilaku konsumsi mereka akan lebih mengacu pada teman-teman sebayanya dari pada keluarga.

Sejalan dengan pendapat tersebut, Peter dan Olson (2010: 335) menyatakan bahwa selain ibu dan ayah, keputusan pembelian pada anak-anak dan orang dewasa keduanya sangat dipengaruhi oleh teman sebaya. Lebih lanjut, Schiffman dan Kanuk (2008: 297) menjelaskan tentang teman sebaya sebagai "kelompok informal, karena biasanya tidak terstruktur dan kurang mempunyai tingkat kewenangan yang khusus. Dari segi pengaruh relatif, sesudah keluarga, teman-teman yang paling mungkin mempengaruhi keputusan pembelian individu."

Lebih lanjut Ormrod (2009: 109) menjelaskan peran teman sebaya dalam perkembangan remaja sebagai hubungan dengan teman sebaya terutama persahabatan karib, memiliki beberapa peran penting dalam perkembangan pribadi dan sosial remaja. Pertamatama, hubungan pertemanan menjadi suatu medan pembelajaran dan pelatihan berbagai keterampilan sosial bagi para remaja, termasuk negosiasi, persuasi, kerjasama, kompromi, kendali emosional, dan penyelesaian konflik. Selain itu, teman sebaya juga memberikan dukungan sosial dan emosional yang sangat dibutuhkan para remaja. Selama masa-masa TK, anak-anak menganggap teman-teman sebayanya terutama sebagai sumber hiburan; namun seiring pertambahan usia, mereka mendapati teman-teman mereka sebagai sumber rasa nyaman dan aman- suatu kelompok tempat mereka bias makan bersama, aman dari anak-anak berandalan. Saat mencapai pubertas, mereka semakin mengandalkan teman sebaya, alih-alih orang tua, untuk mencari dukungan sosial, terutama dalam masa-masa krisis atau kebingungan. Dukungan sosial dari teman sebaya tersebut terutama penting bagi remaja yang berasal dari keluarga yang kurang memberikan kasih sayang atau yang sarat hukuman.

Selanjutnya, Selman \& Selman (dalam Sarwono, 2001: 129) menyimpulkan bahwa pengaruh lingkungan yang pertama adalah pergaulan dengan teman. Pada usia 9-15 tahun hubungan pertemanan adalah hubungan yang akrab dan diikat oleh minat yang sama, kepentingan bersama dan saling membagi perasaan, saling tolong-menolong untuk memecahkan masalah bersama. Dan pada usia 12 tahun ke atas, ikatan emosinya bertambah kuat dan mereka makin saling membutuhkan akan tetapi juga saling memberi kesempatan untuk mengembangkan kepribadiannya masing-masing.

Sementara Chaplin dan John (2010), dalam penelitiannya menyimpulkan bahwa selfesteem memediasi hubungan antara pengaruh orang tua atau teman sebaya dan materialisme pada remaja. Sedangkan Eszter (2008), dalam penelitiannya menemukan bahwa reference group (parents and peers) berpengaruh terhadap perilaku pembelian konsumen remaja. Sementara Makgosa dan Mohube (2007), dalam penelitiannya menemukan bahwa barang mewah yang dikonsumsi di tempat umum (kacamata) secara normatif berpengaruh lebih besar daripada barang mewah yang di konsumsi secara pribadi (telepon seluler) dan barang kebutuhan pokok yang dikonsumsi secara pribadi (pasta gigi). 
Sudah menjadi kebutuhan remaja untuk menjalin hubungan dengan teman-teman sebayanya, ingin diakui, dan menjadi bagian dari kelompok sosialnya. Pencarian jati diri inilah yang membuat anak remaja bergabung dengan teman sebaya atau komunitas tertentu, sibuk mencari identitas diri sendiri dengan bercermin pada teman atau kelompoknya. Mode yang ada dan dipakai dalam kelompok menjadi mode yang perlu untuk mereka ikuti. Mengikuti gaya hidup ini merupakan cara yang paling tepat untuk dapat masuk ke dalam kehidupan kelompok sosial yang mereka idamkan, sehingga konsumsi yang dilakukan sudah tidak lagi didasarkan pada faktor kebutuhan tetapi lebih karena keinginan untuk diterima oleh teman sebayanya.

Lebih lanjut, prestasi belajar siswa juga berhubungan dengan perilaku konsumsi siswa dan teman sebaya. Prestasi belajar oleh Suryabrata (2006: 297) didefinisikan sebagai nilai yang merupakan bentuk perumusan akhir yang diberikan oleh guru terkait dengan kemajuan prestasi belajar siswa selama periode waktu tertentu. Sementara, Saleh (dalam Purwati, 2010) berpendapat bahwa prestasi belajar merupakan hasil yang dicapai siswa dengan mempelajari tingkat penguasaan ilmu pengetahuan tertentu dengan alat ukur berupa evaluasi yang dinyatakan dalam bentuk angka, huruf atau simbol.

Hubungan antara perilaku konsumsi dengan teman sebaya dan prestasi belajar siswa dapat dilihat pada gambar 1, model proses motivasi (Schiffman dan Kanuk, 2008: 72). Menurutnya motivasi sebagai kekuatan dorongan dari dalam diri individu yang memaksa mereka untuk melakukan tindakan. Kekuatan dorongan tersebut dihasilkan dari suatu tekanan yang diakibatkan oleh belum atau tidak terpenuhinya kebutuhan, keinginan, dan permintaan. Kemudian bersama-sama dengan proses kesadaran hasil dari pemikiran dan dan proses belajar individu yang sebelumnya didapat, maka dorongan akan menimbulkan perilaku untuk mencapai tujuan atau pemenuhan kebutuhan. Proses belajar yang maksud diatas dapat diartikan secara luas, yaitu proses belajar disekolah, belajar dari pengalaman sebelumnya, belajar dari melihat dan mendengar dari lingkungan sekitar, serta belajar dari informasi berbagai media.

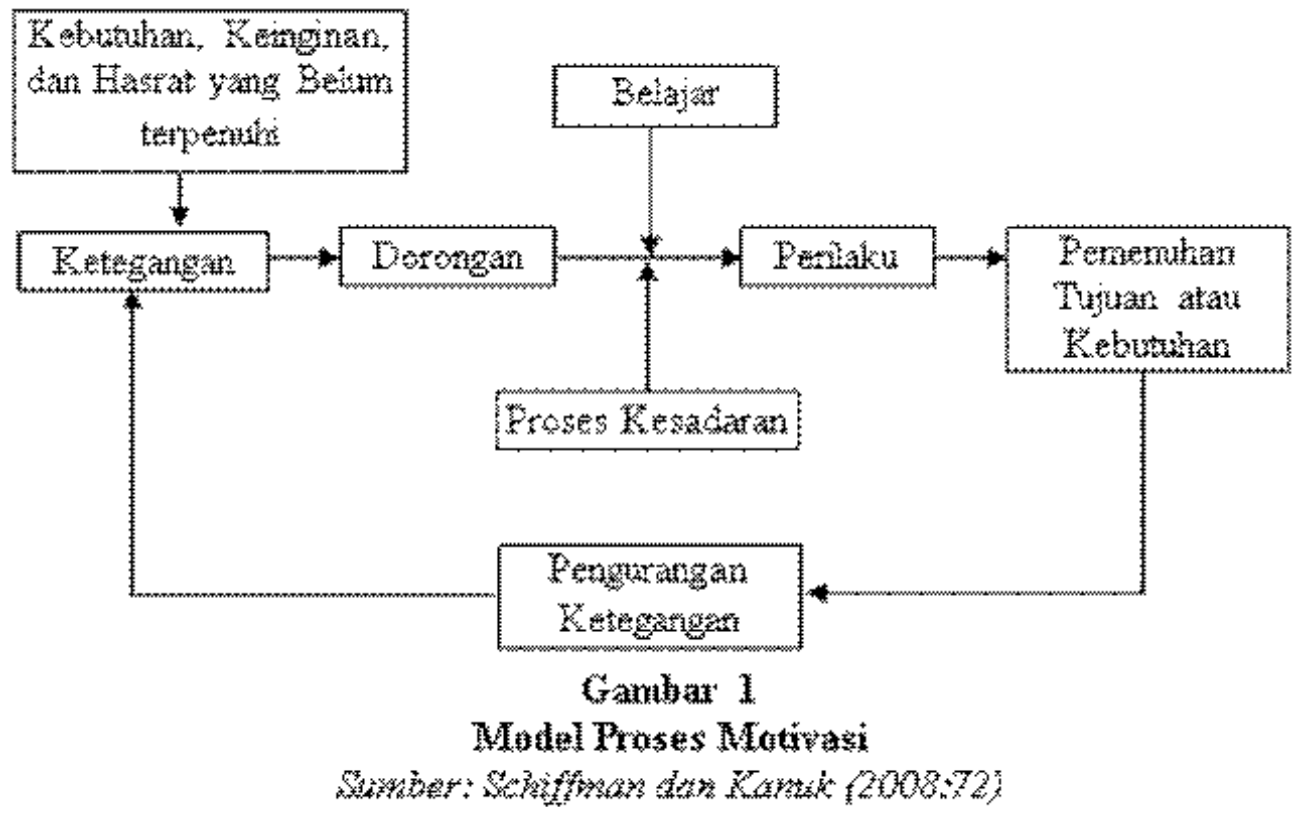

Vol 1, No. 2 Tahun 2013 
Dapat disimpulkan bahwa menurut Schiffman dan Kanuk perilaku seseorang dipengaruhi oleh: kebutuhan, keinginan (yang dapat dipengaruhi oleh teman sebayanya), hasrat yang belum terpenuhi, dan pengalaman belajar serta proses kesadaran yang dimilikinya. Belajar yang dimaksud dalam penelitian ini adalah prestasi belajar ekonomi.

Berbekal pengalaman belajar ekonomi yang baik, diharapkan siswa mampu bertindak dan berperilaku konsumsi yang bijak dan rasional. Hal ini sesuai dengan pendapat Supriya (2009: 213) bahwa mata pelajaran ekonomi bertujuan agar peserta didik memiliki kemampuan sebagai berikut; a) memahami sejumlah konsep ekonomi untuk mengaitkan peristiwa dan masalah ekonomi dengan kehidupan sehari-hari terutama yang terjadi di lingkungan individu, rumah tangga, masyarakat dan negara. b) menampilkan sikap ingin tahu terhadap sejumlah konsep ekonomi yang diperlukan untuk mendalami ilmu ekonomi. c) membentuk sikap bijak rasional dan bertanggung jawab dengan memiliki pengetahuan dan keterampilan ilmu ekonomi, manajemen dan akuntansi yang bermanfaat bagi diri sendiri, rumah tangga, masyarakat dan negara. d) membuat keputusan yang bertanggung jawab mengenai nilai-nilai sosial ekonomi dalam masyarakat majemuk baik skala nasional maupun internasional.

Purwati (2010) menemukan dalam penelitiannya bahwa perilaku konsumsi pada remaja juga dipengaruhi oleh prestasi belajar ekonomi siswa. Penelitiannya membuktikan bahwa prestasi belajar ekonomi berpengaruh positif dan signifikan terhadap perilaku konsumsi siswa. Namun secara empiris berdasarkan penelitian Haryono (2008) kecakapan siswa SMA dalam menggunakan ilmu ekonomi dalam kehidupan sehari-hari atau dalam berperilaku konsumsi, masih sangat jauh dari harapan. Sehingga diharapkan mata pelajaran ekonomi dapat lebih banyak memberikan pengetahuan yang mengarah pada pembentukan sikap untuk menjadikan peserta didik sebagai pelaku ekonomi yang efektif dan efisien berdasarkan pengalaman belajar yang diterimanya.

Dalam Schiffman dan Kanuk (2008: 179) pengalaman adalah sesuatu yang dialami sendiri dan berlaku sebagai umpan balik bagi individu yang pernah mengalaminya dan dapat menjadi dasar bagi perilaku individu tersebut pada masa yang akan datang bila mengalami situasi yang sama. Peran pengalaman ditinjau dari perspektif pemasaran adalah bagian dari pembelajaran konsumen.

Sutisna (2002: 27) menyatakan: "konsumen memperoleh berbagai pengalamannya dalam pembelian produk, mengkonsumsi produk, dan merk produk apa yang disukainya. Konsumen akan menyesuaikan perilakunya dengan pengalamannya di masa lalu." Jadi Sutisna menyimpulkan bahwa "konsumen belajar dari pengalaman masa lalunya, dan perilaku di masa depan diprediksi berdasarkan perilaku masa lalunya." Jadi perilaku konsumsi seseorang itu sangat bergantung pada pengalaman belajarnya. Pengalaman tersebut akan menentukan tindakan dan pengambilan keputusan pembelian.

Proses penentuan tindakan dan pengambilan keputusan konsumen dapat dipelajari pada teori belajar yang dikemukakan oleh Mangkunegara (1988: 48) yang menyampaikan bahwa secara umum teori belajar ada tiga, yaitu: (1) Teori Stimulus Respon. Ahli dalam teori ini adalah: Pavlov, Skinner, dan Hull. Berdasarkan teori ini konsumen akan merasakan puas jika mendapatkan produk, merk dan pelayanan yang menyenangkan. Sebaliknya jika produk, merk dan pelayanan yang diperolehnya dengan tidak menyenangkan akan menjadikan konsumen tidak puas, (2) Teori kognitif. Hilgard dalam teori kognitif menyimpulkan bahwa perilaku konsumen sangat dipengaruhi oleh memorinya terhadap situasi yang terjadi pada masa lampau, masa sekarang dan masa yang akan datang, (3) 
Teori Gestalt dan lapangan yang dikembangkan oleh Gestalt dan Kurt Lewin. Teori ini berpendapat bahwa faktor lingkungan merupakan kekuatan yang sangat berpengaruh pada perilaku konsumen.

Sedangkan penelitian ini mengacu pada aplikasi dari ketiga teori tersebut, yaitu teori stimulus respon, teori kognitif dan teori gestalt dan lapangan karena ketiganya berpengaruh pada perilaku konsumen.

Lebih lanjut,Wahyono (2001) mengungkapkan bahwa manusia adalah makhluk yang rasional karena memiliki kemampuan berpikir, sehingga mampu merencanakan tindakan untuk masa mendatang, berdasarkan pemahaman atas masa lalunya dan kondisi yang dihadapi pada saat ini. Sehingga proses pembelajaran dan pengalaman belajar yang mendukung dalam pengambilan keputusan dalam pembelian itu penting bagi siswa agar dapat membuat keputusan yang baik dan benar dalam perilaku konsumsinya.

Bila ditinjau dari prestasi belajar ekonominya siswa-siswi SMA Khadijah Surabaya memiliki prestasi belajar ekonomi yang cukup baik karena semua siswanya memiliki nilai diatas Kriteria Ketuntasan Minimal (KKM) yaitu 75. Kondisi ini menunjukkan bahwa semua siswa telah tuntas dalam mempelajari materi ekonomi yang telah disampaikan dalam proses pembelajaran. Walaupun demikian belum diketahui apakah prestasi belajar ekonomi siswa tersebut berpengaruh atau tidak terhadap perilaku konsumsi siswa serta mampu membentuk sikap sebagai pelaku ekonomi yang efektif dan efisien berdasarkan pengalaman belajar yang diterimanya. Berdasarkan penjelasan tersebut diatas maka perlu untuk dilakukan penelitian untuk menjawab permasalahan tentang adakah pengaruh teman sebaya dan prestasi belajar ekonomi terhadap perilaku konsumsi siswa.

Beberapa penelitian terdahulu yang berkaitan dengan penelitian ini diantaranya adalah: Suyani (2005), yang menyebutkan bahwa ada hubungan antara status sosial ekonomi orang tua, jumlah uang saku siswa, dan prestasi belajar siswa terhadap sikap berekonomi siswa. Wahyono (2010), yang menyimpulkan bahwa perilaku ekonomi kepala keluarga mempengaruhi intensitas pendidikan ekonomi di lingkungan keluarga. Purwati (2010), faktor status sosial ekonomi orang tua, persepsi atas lingkungan, dan prestasi belajar ekonomi berpengaruh terhadap perilaku konsumsi. Chaplin dan John (2010), menyimpulkan bahwa self-esteem memediasi hubungan antara pengaruh orang tua atau teman sebaya dan materialisme pada remaja. Sugiono (2006), gaya hidup dan psikografi, lingkungan sosial dan fisik kampus mempengaruhi perilaku konsumen dalam pengambilan keputusan berkonsumsi. Eszter (2008), reference group (parents and peers) berpengaruh terhadap perilaku pembelian konsumen remaja. Makgosa dan Mohube (2007), barang mewah yang dikonsumsi di tempat umum (kacamata) secara normatif berpengaruh lebih besar daripada barang mewah yang di konsumsi secara pribadi (telepon seluler) dan barang kebutuhan pokok yang dikonsumsi secara pribadi (pasta gigi). Rensi dan Sugiarti (2010), dukungan sosial, dan konsep diri berpengaruh positif terhadap prestasi belajar siswa secara parsial. Bauer, Sauer, \& Becker (2006), menemukan bahwa terdapat 4 (empat) indikator yang dapat digunakan untuk mengukur perilaku konsumsi atas berbagai macam kategori produk, yang disebut dengan CDMS.

Berdasarkan pendahuluan yang telah diuraikan sebelumnya, maka dapat dirumuskan beberapa hipotesis sebagai berikut:

1. Diduga ada pengaruh signifikan teman sebaya terhadap perilaku konsumsi siswa SMA Khadijah Surabaya.

2. Diduga ada pengaruh signifikan prestasi belajar ekonomi terhadap perilaku konsum- 
si siswa SMA Khadijah Surabaya.

3. Diduga ada pengaruh signifikan teman sebaya dan prestasi belajar ekonomi secara bersama-sama terhadap perilaku konsumsi siswa SMA Khadijah Surabaya.

\section{METODE PENELITIAN}

Pendekatan dalam penelitian ini adalah pendekatan kuantitatif. Penelitian ini dirancang dengan menggunakan penelitian eksplanatori. Variabel yang digunakan pada penelitian ini adalah teman sebaya (X1), prestasi belajar ekonomi (X2), dan perilaku konsumsi siswa $(\mathrm{Y})$.

Perilaku konsumsi siswa yang dimaksud dalam penelitian ini adalah tindakan yang menjadi refleksi dari pengambilan keputusan yang dilakukan siswa dalam mencari, membeli, menggunakan, mengevaluasi, dan menentukan tindakan sesudah mengkonsumsi suatu produk, jasa maupun ide yang diharapkan dapat memuaskan kebutuhan mereka. Indikator yang digunakan untuk mengukur perilaku konsumsi siswa ini adalah kesetiaan terhadap merk/ toko, pembelian impulsif, kesadaran terhadap harga dan kualitas, dan pencari variasi.

Selanjutnya teman sebaya dalam penelitian ini didefinisikan sebagai kelompok rujukan yang mempengaruhi sikap dan perilaku konsumen yang biasa disebut dengan istilah kelompok persahabatan. Indikator yang digunakan dalam penelitian ini untuk mengukur variabel teman sebaya adalah kerentanan terhadap pengaruh interpersonal dan perhatian terhadap informasi perbandingan sosial.

Sedangkan prestasi belajar ekonomi yang dimaksud dalam penelitian ini adalah hasil kegiatan belajar ekonomi siswa yang diterima dan dimiliki oleh siswa selama satu semester yang sudah disimpulkan dalam bentuk nilai akhir yang dimasukkan dalam nilai rapor mata pelajaran ekonomi semester ganjil 2012-2013.

Populasi dalam penelitian ini adalah siswa kelas X SMA Khadijah Surabaya yaitu sebanyak 192 siswa. Sampel dalam penelitian ditetapkan dengan teknik simple random sampling menggunakan rumus Slovin sebanyak 130 orang. Pengumpulan data penelitian dilakukan dengan menyebarkan kuesioner atas variabel perilaku konsumsi dan teman sebaya serta mengumpulkan data dokumentasi berupa nilai rapor mata pelajaran ekonomi semester ganjil tahun pelajaran 2012-2013.

Teknik analisis menggunakan analisis regresi berganda dengan menggunakan uji t dan uji F. Uji t digunakan untuk menguji signifikansi pengaruh teman sebaya terhadap perilaku konsumsi siswa dan pengaruh prestasi belajar ekonomi terhadap perilaku konsumsi siswa. Sedangkan uji F digunakan untuk menguji signifikansi pengaruh variabel teman sebaya dan prestasi belajar ekonomi terhadap perilaku konsumsi siswa.

\section{HASIL PENELITIAN DAN PEMBAHASAN}

\section{Hasil Penelitian}

\section{Deskripsi Variabel Penelitian}

\section{Perilaku konsumsi Siswa}

Berdasarkan kondisi perilaku konsumsi siswa di SMA Khadijah Surabaya secara keseluruhan tergolong dalam kategori cukup tinggi. Skor rata-rata atas indikator perilaku konsumsi siswa yang tertinggi adalah kesadaran terhadap harga dan kualitas, dan yang 
terendah adalah kesetiaan terhadap merk/toko. Secara lengkap perolehan skor rata-rata indikator perilaku konsumsi siswa sebagai berikut: kesetiaan terhadap merk/toko (dalam kategori sangat rendah sebanyak 28,21\%; berkategori rendah sebanyak 27,35\%; dan berkategori sedang sebanyak 44,44\%), pembelian implusif (dalam kategori sangat rendah sebanyak $28,85 \%$, dan berkategori rendah sebanyak $71,15 \%$ ), kesadaran terhadap harga dan kualitas (dalam kategori sangat rendah sebanyak 24,62\%; berkategori rendah sebanyak $32,05 \%$; dan berkategori sedang sebanyak 43,33\%), dan pencari variasi (dalam kategori sangat rendah sebanyak 23,85\%; berkategori rendah sebanyak $25,77 \%$; dan berkategori sedang sebanyak 50,38\%).

\section{Teman Sebaya}

Berdasarkan kondisi teman sebaya di SMA Khadijah Surabaya secara keseluruhan tergolong dalam kategori cukup tinggi. Skor rata-rata atas kedua indikator variabel teman sebaya adalah sama. Secara lengkap perolehan skor rata-rata indikator variabel teman sebaya sebagai berikut: Kerentanan terhadap pengaruh interpersonal (dalam kategori sangat rendah sebanyak 32,44\%; berkategori rendah sebanyak 27,44\%; dan berkategori sedang sebanyak 40,13\%), dan Perhatian terhadap informasi perbandingan sosial (dalam kategori sangat rendah sebanyak $21,54 \%$; berkategori rendah sebanyak $25,38 \%$; dan berkategori sedang sebanyak 53,08\%).

\section{Prestasi belajar.}

Berdasarkan kondisi prestasi belajar ekonomi siswa di SMA Khadijah Surabaya secara keseluruhan mendapatkan nilai rata-rata 79,9 yang tergolong dalam kriteria cukup baik. Prestasi belajar ekonomi siswa terendah adalah 78 dan prestasi belajar ekonomi siswa tertinggi adalah 84 .

Secara lengkap prestasi belajar ekonomi siswa dapat disarikan sebagai berikut: nilai 78 - 79,5 (dalam kategori kurang baik) sebanyak 44,62\%, nilai 79,6 - 81,0 (dalam kategori cukup baik) sebanyak 41,54\%, nilai 81,1 - 82,5 (dalam kategori baik) sebanyak $6,92 \%$, dan nilai $82,6-84$ (dalam kategori sangat baik) sebanyak 6,92\%.

\section{Persamaan Regresi}

Persamaan regresi berdasarkan hasil penelitian ini dituliskan sebagai berikut:

$\mathrm{Y}=-1,425+0,469 \mathrm{X} 1+0,041 \mathrm{X} 2+\mathrm{e}$. Dari persamaan tersebut dapat dijelaskan bahwa:

a. Konstanta (a) yang dihasilkan sebesar-1,425. Hal ini berarti besarnya perilaku konsumsi siswa dianggap nol atau kosong (karena arahnya negatif) jika variabel teman sebaya dan prestasi belajar ekonomi adalah konstan atau nol.

b. Koefisien regresi pada variabel teman sebaya adalah positif yaitu sebesar 0,469 . Artinya jika teman sebaya naik satu satuan, maka perilaku konsumsi siswa akan naik sebesar 0,469 dengan asumsi variabel prestasi belajar ekonomi adalah konstan.

c. Koefisien regresi pada variabel prestasi belajar ekonomi adalah positif yaitu sebesar 0,041. Artinya jika prestasi belajar ekonomi naik satu satuan, maka perilaku konsumsi siswa akan naik sebesar 0,041 dengan asumsi variabel teman sebaya adalah konstan.

Uji F digunakan untuk mengetahui pengaruh teman sebaya dan prestasi belajar ekonomi terhadap perilaku konsumsi siswa. Hasil uji F menunjukkan nilai Fhitung sebesar 
27,721 dengan signifikansi 0,000 lebih kecil dari 5\%. Hal ini berarti bahwa teman sebaya dan prestasi belajar ekonomi secara simultan berpengaruh terhadap perilaku konsumsi siswa.

Koefisien determinasi (R-square) yang dihasilkan dalam penelitian ini sebesar 0,304 menunjukkan bahwa teman sebaya (X1) dan prestasi belajar ekonomi (X2) berpengaruh terhadap perilaku konsumsi siswa (Y) sebesar 30,4\% sedangkan sisanya 69,6\% dipengaruhi oleh faktor lain yang tidak dibahas pada penelitian ini.

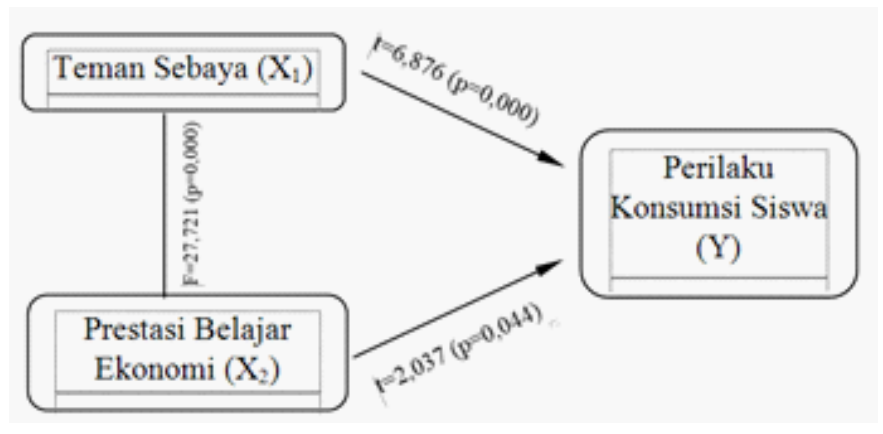

Gambar 2 Hasil Uji Hipotesis

\section{Pembahasan}

1. Pengaruh Teman Sebaya terhadap Perilaku Konsumsi Siswa SMA Khadijah Surabaya

Berdasarkan hasil penelitian mengenai pengaruh teman sebaya terhadap perilaku konsumsi siswa menunjukkan bahwa teman sebaya secara parsial berpengaruh positif dan signifikan terhadap perilaku konsumsi siswa. Hipotesis kerja yang menyatakan "Diduga ada pengaruh signifikan teman sebaya terhadap perilaku konsumsi siswa SMA Khadijah Surabaya" teruji kebenarannya. Hal ini ditunjukkan dari nilai thitung pada teman sebaya (X1) sebesar 6,876 dengan tingkat signifikan sebesar 0,000 lebih kecil dari 5\%. Sedangkan besarnya pengaruh teman sebaya (X1) terhadap perilaku konsumsi siswa (Y) adalah $27,14 \%$.

Adanya pengaruh teman sebaya terhadap perilaku konsumsi siswa dibuktikan dengan data responden pada variabel teman sebaya atas indikator kerentanan terhadap pengaruh interpersonal menunjukkan bahwa siswa-siswi SMA Khadijah Surabaya sering bertanya pada teman sebayanya tentang suatu produk jika hanya memiliki sedikit pengetahuan dan pengalaman tentang suatu produk. Siswa juga sering mencari informasi dari teman sebaya mereka tentang sebuah produk sebelum membelinya. Selain itu untuk memastikan bahwa mereka membeli produk dan merk yang tepat, mereka sering melakukan observasi atas apa yang dibeli dan digunakan oleh teman sebaya mereka.

Hasil angket atas indikator yang sama juga menunjukkan bahwa siswa-siswi SMA Khadijah hanya membeli busana dengan model terbaru setelah mereka yakin bahwa teman sebaya mereka menyukainya. Hal ini mereka lakukan karena mereka ingin diterima oleh teman teman sebaya mereka dan mendapatkan rasa aman. Bahkan lebih dari itu, siswa-siswi SMA Khadijah Surabaya bahkan sering mengidentikkan (menyamakan) diri mereka dengan teman-teman sebaya mereka dengan cara membeli produk dan merk yang sama dengan yang teman sebaya mereka beli agar memiliki persamaan dengan teman sebaya mereka. Selain itu mereka juga sering membeli produk dengan merk yang diharap- 
kan oleh teman sebaya untuk mereka beli atas produk-produk yang penggunaannya dapat dilihat oleh teman sebaya mereka misal: jam tangan, handphone, pakaian, dan laptop.

Sedangkan untuk indikator perhatian terhadap informasi perbandingan sosial didapatkan data bahwa siswa-siswi SMA Khadijah sering mencoba untuk berperilaku dengan cara yang memungkinkan mereka untuk menyesuaikan diri dengan teman sebaya mereka saat berada dalam suatu acara. Selain itu siswa-siswi SMA Khadijah Surabaya juga cenderung memperhatikan apa yang dikenakan oleh teman-temannya. Hal ini menunjukkan bahwa teman sebaya memang berpengaruh dalam perilaku konsumsi siswa SMA Khadijah Surabaya.

Lebih lanjut, dari angket terbuka dapat disimpulkan bahwa siswa kelas X SMA Khadijah memiliki uang saku yang bervariasi dengan besaran uang saku yang terbilang cukup tinggi bagi ukuran uang saku siswa SMA. Selain dikonsumsikan untuk memenuhi kebutuhannya uang saku siswa tersebut sebagian juga ada yang disisihkan/ditabung. Dari data yang diperoleh diketahui bahwa jumlah siswa yang menabung jauh lebih tinggi dibandingkan jumlah siswa yang tidak menabung. Ini menunjukkan bahwa sebagian besar siswa kelas X SMA Khadijah Surabaya gemar menabung. Kondisi ini menunjukkan positifnya pengaruh teman sebaya dalam perilaku konsumsi siswa di SMA Khadijah Surabaya. Karena teman yang gemar menabung memberi pengaruh baik terhadap teman sebayanya.

Selain itu, hasil angket juga menunjukkan bahwa siswa SMA Khadijah suka mencoba membeli berbagai macam produk dari berbagai macam merk. Demi memenuhi kesenangan untuk mencoba membeli berbagai macam merk, mereka berbelanja di beberapa toko yang berbeda dan memilih merk yang berbeda pula. siswa juga memiliki kecenderungan untuk merencanakan kegiatan belanjanya dengan lebih berhati-hati, dan mereka biasanya bisa menghemat uang dengan berkeliling mencari barang di toko dengan harga termurah. Selain itu uang saku siswa SMA Khadijah yang diatas rata-rata uang saku siswa SMA pada umumnya dan adanya pengaruh teman sebaya yang suka jalan-jalan ke mall juga mempengaruhi mereka untuk melakukan hal yang sama. Jalan-jalan ke mall tersebut mereka lakukan untuk mengetahui trend dan mode yang terbaru sekaligus sebagai sarana bersosialisasi dengan teman sebaya mereka. Dengan demikian, jelas bahwa teman sebaya dapat mempengaruhi perilaku konsumsi siswa SMA Khadijah Surabaya. Sesuai dengan teori yang dikemukakan oleh Schiffman dan Kanuk (2008: 308) yang menegaskan bahwa para remaja yang berusia belasan tahun mungkin menjadikan teman sebaya mereka sebagai model perilaku konsumsi yang dapat diterima. Jadi bagi remaja yang berusia belasan tahun, perilaku konsumsi mereka akan lebih mengacu pada teman-teman sebayanya.

Hasil penelitian ini didukung oleh teori yang disampaikan Schiffman dan Kanuk (2008: 297) yang menyatakan bahwa: "Pendapat dan pilihan teman-teman merupakan pengaruh yang penting dalam menentukan produk atau merk yang akhirnya dipilih konsumen."

Hasil penelitian ini sejalan dengan hasil penelitian Makgosa dan Mohube (2007) yang menemukan bahwa teman sebaya berpengaruh terhadap perilaku konsumsi atas barang mewah yang dikonsumsi di tempat umum, misalnya kacamata secara normatif berpengaruh lebih besar daripada barang mewah yang dikonsumsi secara pribadi (telepon seluler) dan barang kebutuhan pokok yang dikonsumsi secara pribadi (pasta gigi). Hasil penelitian ini juga mendukung penelitian Eszter (2008) yang menyimpulkan bahwa reference group (termasuk teman sebaya) berpengaruh terhadap perilaku pembelian konsumen remaja. 
2. Pengaruh Prestasi Belajar Ekonomi terhadap Perilaku Konsumsi Siswa SMA Khadijah Surabaya

Hasil penelitian ini menemukan bahwa nilai t-hitung pada variabel prestasi belajar ekonomi (X2) sebesar 2,037 dengan tingkat signifikan kurang dari $5 \%$ yaitu 0,044 . Hal ini berarti prestasi belajar ekonomi (X2) secara parsial berpengaruh signifikan terhadap perilaku konsumsi siswa (Y). Besarnya pengaruh prestasi belajar ekonomi (X2) terhadap perilaku konsumsi siswa (Y) adalah 31,68 \%.

Pengaruh prestasi belajar ekonomi (X2) terhadap perilaku konsumsi siswa (Y) lebih besar daripada pengaruh teman sebaya (X1) terhadap perilaku konsumsi siswa (Y). Hal ini terjadi karena prestasi belajar siswa kelas X SMA Khadijah Surabaya memiliki ratarata nilai rapor yang cukup baik, dengan nilai prestasi belajar terendah adalah 78 sebanyak 27 orang siswa $(20,8 \%)$, dan prestasi belajar tertinggi adalah 84 sebanyak 3 orang siswa $(2,3 \%)$, dengan nilai rata-rata yaitu 79,9 yang berarti rata-rata siswa memiliki prestasi belajar yang tergolong dalam kriteria cukup baik. Sehingga secara parsial prestasi belajar ekonomi (X2) berpengaruh terhadap perilaku konsumsi siswa (Y) pada mata pelajaran ekonomi.

Hasil penelitian ini sesuai dengan teori yang diungkapkan oleh Schiffman dan Kanuk (2008: 72) bahwa motivasi sebagai kekuatan dorongan dari dalam diri individu, memaksa mereka untuk melakukan tindakan. Kekuatan dorongan tersebut dihasilkan dari suatu tekanan yang diakibatkan oleh belum atau tidak terpenuhinya kebutuhan, keinginan, dan permintaan. Kemudian bersama-sama dengan proses kesadaran hasil dari pemikiran dan proses belajar individu yang sebelumnya didapat, maka dorongan akan menimbulkan perilaku untuk memenuhi kebutuhan.

Sejalan dengan teori diatas Supriya (2009: 213) mengemukakan bahwa mata pelajaran ekonomi bertujuan agar peserta didik memiliki kemampuan sebagai berikut: 1) memahami sejumlah konsep ekonomi untuk mengaitkan peristiwa dan masalah ekonomi dengan kehidupan sehari-hari terutama yang terjadi di lingkungan individu, rumah tangga, masyarakat dan negara, 2) menampilkan sikap ingin tahu terhadap sejumlah konsep ekonomi yang diperlukan untuk mendalami ilmu ekonomi, 3) membentuk sikap bijak rasional dan bertanggung jawab dengan memiliki pengetahuan dan keterampilan ilmu ekonomi, manajemen dan akuntansi yang bermanfaat bagi diri sendiri, rumah tangga, masyarakat dan negara, 4) membuat keputusan yang bertanggung jawab mengenai nilai-nilai sosial ekonomi dalam masyarakat majemuk baik skala nasional maupun internasional.

Hasil penelitian ini mendukung hasil penelitian Purwati (2010). Penelitian Purwati tersebut menemukan bahwa status sosial ekonomi orang tua siswa, persepsi atas lingkungannya, dan prestasi belajar ekonomi berpengaruh positif dan signifikan terhadap perilaku konsumsi siswa.

\section{Pengaruh Teman Sebaya dan Prestasi Belajar terhadap Perilaku Konsumsi Siswa SMA Khadijah Surabaya}

Secara parsial teman sebaya berpengaruh signifikan terhadap perilaku konsumsi siswa, demikian juga prestasi belajar ekonomi. Secara simultan pun kedua variabel tersebut, baik teman sebaya maupun prestasi belajar ekonomi berpengaruh signifikan terhadap perilaku konsumsi siswa. Hal ini dapat dilihat dari nilai $F$ hitung sebesar 27,721 dengan nilai signifikan sebesar 0,000 lebih kecil dari 5\%. Sedangkan nilai $R$-square yang dihasil- 
kan sebesar 0,304 menunjukkan bahwa perilaku konsumsi siswa dipengaruhi oleh teman sebaya dan prestasi belajar ekonomi sebesar 30,4\% sedangkan $69,6 \%$ dipengaruhi oleh faktor-faktor lain selain variabel teman sebaya dan prestasi belajar ekonomi.

Hasil penelitian ini menunjukkan bahwa teman sebaya berpengaruh terhadap perilaku konsumsi siswa kelas X SMA Khadijah Surabaya sebesar 27,14\%. Hal ini disebabkan bahwa siswa SMA Khadijah Surabaya sering bertanya pada teman sebayanya tentang suatu produk jika hanya memiliki sedikit pengetahuan dan pengalaman tentang produk, sering mencari informasi dari teman-teman tentang sebuah produk sebelum membelinya, mencoba untuk berperilaku dengan cara yang memungkinkan untuk menyesuaikan diri dengan teman-temannya, dan cenderung untuk memperhatikan apa yang dikenakan oleh teman sebayanya.

Sedangkan prestasi belajar ekonomi yang dimiliki oleh siswa kelas X SMA Khadijah Surabaya berpengaruh lebih tinggi terhadap perilaku konsumsi siswa daripada variabel teman sebaya, yaitu sebesar 31,68 \%. Hal ini terjadi karena prestasi belajar ekonomi siswa kelas X SMA Khadijah Surabaya memiliki rata-rata nilai rapor yang cukup baik, dengan nilai prestasi belajar terendah adalah 78 dan prestasi belajar tertinggi adalah 84, dengan nilai rata-rata yaitu 79,9 yang berarti rata-rata siswa memiliki prestasi belajar yang tergolong dalam kriteria cukup baik.

\section{KESIMPULAN}

Berdasarkan hasil penelitian dan pembahasan, maka dapat disimpulkan bahwa:

1. Teman sebaya berpengaruh signifikan terhadap perilaku konsumsi siswa. Hal ini berarti semakin banyak teman sebaya, maka pengaruhnya terhadap perilaku konsumsi siswa semakin tinggi.

2. Prestasi belajar ekonomi berpengaruh signifikan terhadap perilaku konsumsi siswa. Hal ini berarti semakin tinggi prestasi belajar ekonomi siswa, maka pengaruhnya terhadap perilaku konsumsi siswa semakin tinggi.

3. Teman sebaya dan prestasi belajar ekonomi secara bersama-sama berpengaruh signifikan terhadap perilaku konsumsi siswa. Hal ini berarti semakin banyak teman sebaya dan semakin tinggi prestasi belajar ekonomi siswa, maka pengaruhnya terhadap perilaku konsumsi siswa semakin tinggi.

Saran-saran yang dapat direkomendasikan sebagai tindak lanjut hasil penelitian adalah sebagai berikut:

1. Bagi siswa disarankan untuk berupaya meningkatkan prestasi belajar ekonominya agar memiliki perilaku konsumsi yang semakin baik pula, karena pengetahuan yang dimiliki dapat menjadikan siswa lebih bijak, rasional dan bertanggung jawab dalam perilaku konsumsinya.

2. Bagi guru ekonomi disarankan untuk dapat membekali siswa dengan ilmu dan pengetahuan ekonomi yang aplikatif dalam kehidupan serta mengembangkan sikap dan perilaku siswa yang bijak, rasional dan bertanggung jawab dalam perilaku konsumsi siswanya.

3. Bagi peneliti berikutnya disarankan untuk dapat mengembangkan penelitian yang berkaitan dengan teman sebaya, prestasi belajar ekonomi, dan perilaku konsumsi siswa ini secara lebih lanjut dengan mengembangkan variabel-variabel lain yang 
dapat mempengaruhinya. Mengingat keterbatasan penelitian ini yang hanya meneliti SMA Khadijah Surabaya yang berada di kota, maka disarankan agar peneliti berikutnya dapat meneliti di sekolah yang berada di daerah pinggiran agar dapat membandingkan perilaku konsumsi siswa yang berada di perkotaan dan perilaku konsumsi siswa yang berada di daerah pinggiran.

\section{DAFTAR RUJUKAN}

Bauer, Hans H., Sauer, Nicola E. \& Becker, Christine. 2006. "Investigating the Relationship Between Product Involvement and Consumer Decision-Making Styles". Journal of Consumer Behaviour. 5: 342-354.

Chaplin, Lan Nguyen \& John, Deborah Roedder. 2010. "Interpersonal Influences on Adolescent Materialism: A New Look at The Role of Parents and Peers". Journal of Consumer Psychology 20, pp. 176-184.

Eszter, Tarkanyi. 2008. The Role of Reference Group Influence in Consumer Behaviour. Szechenyi Istvan University.

Haryono, A. 2008. "Pengaruh Proses Pembelajaran, Penilaian Hasil Belajardan Status Sosial Ekonomi Terhadap Tingkat Economic Literacy Siswa SMA di Kota Malang”. Disertasi. Malang: PPS UM.

Hoyer, Wayne D \& MacInnis, Deborah J. 2008. Consumer Behavior. 5th Edition. Canada: Cengage Learning.

Kotler, P \& Amstrong, G. 2012. Principle of Marketing. 14th edition. New Jersey: Prentice-Hall, Inc.

Makgosa, R. \& Mohube, K. 2007. Peer Influence on Young Adults' Products Purchase Decisions. African Journal of Business Management. Pp. 064-071. June 2007. (available online http://www.academicjournals.org/ajbm).

Mokhlis, Safiek \& Salleh, Hayatul Safrah. 2009. Consumer Decision-Making Styles in Malaysia: An Exploratory Study of Gender Differences. European Journal of Social Sciences. Vol. 10, No. 4, pp. 574-584.

Ormrod, Jeanne Ellis. 2009. Psikologi Pendidikan Membantu Siswa Tumbuh dan Berkembang. Edisi ke 6, jilid 1. Jakarta: Penerbit Erlangga.

Peter, J. Paul \& Olson, Jerry C. 2010. Consumer Behavior \& Marketing Strategy. 9th edition. New York: McGraw-Hill/Irwin.

Purwati, Ana. 2010. "Pengaruh Status Sosial Ekonomi Orang Tua, Persepsi atas Lingkungannya, dan Prestasi Belajar Ekonomi terhadap Perilaku Konsumsi". Jurnal Ekonomi Bisnis, Th.16, No. 1, Maret 2011, hal. 11-16.

Rensi dan Sugiarti, Lucia Rini. 2010. Dukungan Sosial, Konsep Diri, dan Prestasi Belajar Siswa SMP Kristen YSKI Semarang. Jurnal Psikologi. Vol. 3. No. 2. Hal. 148-153. 
Sarwono, Sarlito W. 2001. Psikologi Remaja. Jakarta: PT RajaGrafindo Persada.

Schiffman, L. G \& Kanuk, L.L. 2008. Perilaku Konsumen. Edisi ke 7. Jakarta: PT Indeks.

Sugiono. 2006. “Analisis tentang Faktor-faktor yang Mempengaruhi Perilaku Konsumen (Tinjauan Teori)". Jurnal Aplikasi Manajemen. vol. 4. No. 2. hal. 197-205.

Supriya. 2009. Pendidikan IPS. Bandung: PT Remaja Rosdakarya.

Suryabrata. 2004. Psikologi Pendidikan. Jakarta: PT Raja Grafindo Persada.

Suyani, S. 2005. "Hubungan antara Status Sosial Ekonomi Orang Tua dan Jumlah Uang Saku terhadap Sikap Berekonomi Siswa di MAN 3 Malang yang dibedakan menurut Prestasi Belajar". Tesis. Malang: PPS UM.

Wahyono, H. 2001. "Pengaruh Perilaku Ekonomi Kepala Keluarga terhadap Intensitas Pendidikan Ekonomi di Lingkungan Keluarga". Disertasi. Malang: PPS UM. 